\title{
Macroinvertebrate benthic community as rapid quality assessment in Winongo, Code, and Gajahwong Streams inside Yogyakarta City, Special Region of Yogyakarta Province
}

\author{
Suwarno Hadisusanto ${ }^{1, *}$, Dwinda Mariska Putri ${ }^{1}$, Puguh Sujarta $^{1}$, Raditia Nugraha $^{1}$, Qisti Fauziyah $^{1}$, \\ Riska Putri Asmawati ${ }^{1}$, Annisa Mawarni ${ }^{1}$, Firda Nabila Nur Azizah ${ }^{1}$, and Muhammad Rifqi ${ }^{1}$ \\ ${ }^{1}$ Laboratory of Ecology and Conservation, Faculty of Biology, Universitas Gadjah Mada, Sleman, Yogyakarta, 55280, Indonesia
}

\begin{abstract}
Streams in Yogyakarta City are classified as an urban river, they receive huge amount of organic matter daily from anthropogenic waste. Growing urbanization affected water ecosystem causing water quality and benthic community changes. Macroinvertebrate benthic immediately respond to physicchemical changes of the stream. Aims of this study are studying urbanization alter macroinvertebrate benthic community, and water quality in Winongo, Gajahwong, and Code streams of Yogyakarta City. Samples were collected at December 2015 and January 2017 in Winongo, Gajahwong, and Code streams inside the administration area of Yogyakarta City using sediment Dredge. Collections perform by dividing each stream into three parts with five replications. Macroinvertebrate benthic were filtered using stratified filter mesh 60, 40, and 20 results showed that macroinvertebrate benthic diversity decreasing from 2015 to 2017 in these three urban streams. There were not much species founded in Yogyakarta City Streams, indicates riparian ecosystem lack of natural habitat. All riparian zone are damage by anthropogenic activities. Their density is also decreasing probably because riparian floodplain embankment caused water velocity faster, leave little sediment for benthic organism. Chironomids larvae dominate in all stations in each river, and the most abundant in Code. They were abundant because streams in Yogyakarta City accept high input of organic matter. They classified as tolerate groups where their abundance indicates water pollution. High waterfall during 2016 most probably caused water quality better in 2017 than 2015 . Dissolved oxygen was higher, and water ph is closer to neutral. Thus it cannot be used as an indicator.
\end{abstract}

\section{Introduction}

Stream is an open ecosystem that it conditions strongly affected by its surrounding environments [1]. In an urban area, streams accept direct input of organic and chemical waste from anthropogenic activitiesincreased urban area associated with the amount and variety of pollutant in runoff. Thus responsible for warming of surface runoff on exposed area adding sediment inputs [2]. Study proved that urban streams in industrial area have $\mathrm{N}$ and $\mathrm{P}$ concentrations higher than streams in less developed area [3]. High nutrient concentration in streams water body triggered faster metabolic and respiration rate of microorganisms lead to high biological oxygen demand [4].

Conducting biomonitoring of streams' organisms are effective as one of the effort to manage water resource quality in both developed country also in developing country [5-7]. Macroinvertebrate benthic community is commonly used as streams bioindicators. They are quite sensitive in responding to streams physical and chemical changes, have a variety of higher taxa, limited mobility, long life cycle, easy to sample, and easy to identified [8-13]. Distribution and abundance of macroinvertebrate benthic are driven by several factors such as habitat characteristic, water

\footnotetext{
Corresponding author: suwarnohs@ugm.ac.id
}

quality, pollutant, stream beds sediment characters, and biological factors including predators and competition [14]. The concept of indicator species is using presence and/or absence characteristic taxa to the degree of their respond to environmental changes. Some macrobenthic species are very specific under river conditions wether clean or polluted. It helps in determining river's health [15].

Yogyakarta City has three major streams they are Winongo, Code, and Gajahwong. Growing urbanization, and population growth lead by a citizen is built more residence right next to these streams. Due to low budget and high demand, these residence has poor sanitation and no sewage treatment. Consequently, streams in Yogyakarta City are severe for high organic effluent. Industrial and hospital are also responsible for chemical pollutions. These anthropogenic activities can lower streams water quality and cause streams can't support its function as water resources also for fisheries. There have been issues that streams in Yogyakarta City have coliform bacteria and organic matter that exceed environmental quality standards. Badan Lingkungan Hidup Daerah Istimewa Yogyakarta had done several activities to reduce pollutants. They need an easy and effective method to help them monitoring streams health also strategy to make citizens aware of the importance of the streams [16- 
18]. We compare macroinvertebrate benthic community in three streams, which streams showed better water quality, to understand which stream needs more attention and we compared data in 2015 and 2017 to study water quality through times and how it affected the macrobenthic community.

\section{Methods}

\subsection{Study sites}

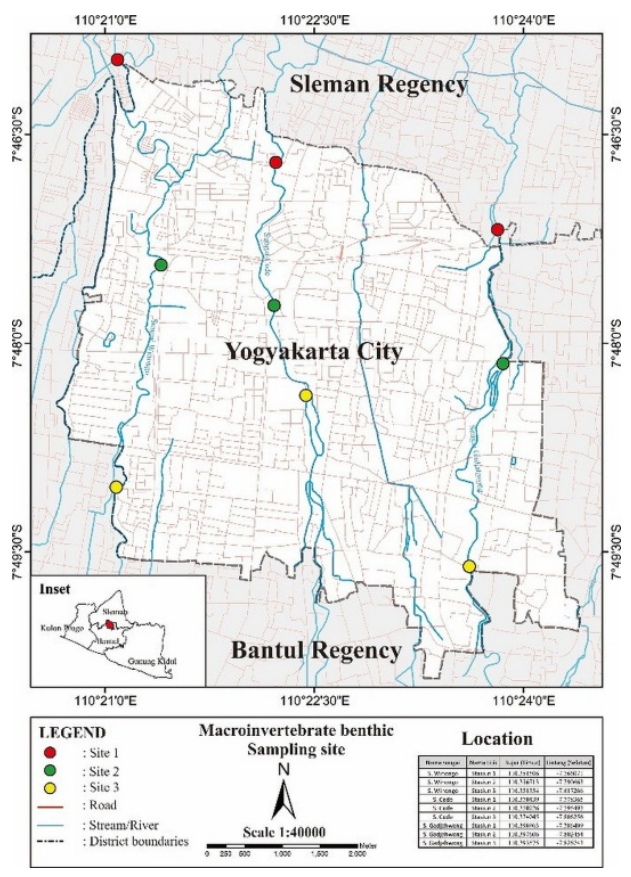

Fig. 1. Study sites of Winongo, Code, and Gajahwong Streams in Yogyakarta. $\mathrm{O}=$ study site.

This study was conducted on three separate streams inside the administation area of Yogyakarta City, marked by dotted-line (Figure 1). The streams were Winongo, Code, and Gajahwong. These streams are classified as urban streams ecosystem, each stream has $7.06 \mathrm{~km}, 8.73 \mathrm{~km}$, and $6.03 \mathrm{~km}$ in length. These streams receive huge amount of nutrient daily. Sources of nutrient are from domestic, industrial, and hospital waste.

Three sampling stations were positioned in each stream at a time. Winongo stream site 1 is located in Tegal Rejo District, in the middle of residence and beside main road (110 $21^{\prime} 055^{\prime \prime}$ E $7^{\circ} 45^{\prime} 577^{\prime}$ 'S). Site 2

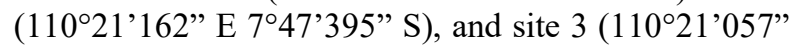
E 749’024" S) located in Wirobrajan District. In site 2 , there are land transformations from the river bank to residence. Site 3 was used for sand mining in a minor scale, residence, and empty land.

Code stream sites were located in: site 1 $\left(110^{\circ} 22^{\prime} 231^{\prime \prime} \mathrm{E} 7^{\circ} 46^{\prime} 703\right.$ ” S), site 2 (110²2'133” E $\left.7^{\circ} 47^{\prime} 485^{\prime \prime} \mathrm{S}\right)$, and site 3 (110²2'270" E 748'233” S). Site 1, 2, and 3 are located in Jetis District, Gondomanan District, and Mergasan District respectively. There is land converted from river bank to residence in each site. And for site 2, there are flats build by the government right on the river bank.
Gajahwong river site 1 located in Umbulharjo $\left(110^{\circ} 23^{\prime} 805^{\prime \prime} \mathrm{E} 7^{\circ} 46^{\prime} 960^{\prime \prime} \mathrm{S}\right)$, site 2 (110²3'573” E 7०48'103” S) and site 3 (110²3'368” E 748’349” S) is in Kotagede District. Every site was used for residence. In site 2 there is waste from factory and zoo, and there is minor sand mining on site 3 .

\subsection{Data collection}

Samples were collected in 12-13 December 2015, and 31 December 2016-1 January 2017. Sampling date was different due to heavy rainfall that can causemacroinvertebrate benthic community washed away. Sampling conducted after three days with no rain. Macroinvertebrate benthic was sampled by dredge Petersen 1 L. Samples were moved to collection bottle and preserved by 3 drops of formaldehyde $4 \%$. At each station, environmental parameters including air and water temperature were measured using a thermometer, air relative humidity using hygrometer, and light intensity using lux meter. Samples of water were collected using dark bottles. Dissolved oxygen concentrations were measured using DO meter, alkalinity using alkali kit, $\mathrm{CO}_{2}$ content using the $\mathrm{CO}_{2}$ kit, and water $\mathrm{pH}$ using $\mathrm{pH}$ meter.

Sediment samples were filtered by stratified filter size: 20, 40 and 60 mesh Samples preserved in alcohol $70 \%$ with ratio volume sample:alcohol (1:3). Samples were placed on petri disk then observed using a stereo microscope. Next, samples were counted and identified using Immature Insects Volume 1-2 (1987, 1991) Frederick W. Stehr Kendall/Hunt Publishing Company.

\subsection{Data analysis}

Density of species A

$$
D=\frac{\text { number of individu species } A}{\text { unit area }}
$$

\section{Relative Density}

$D R=\frac{\text { number of individu species } A}{\text { number of individuals of all species }} \times 100 \%$

\section{Frequency}

$$
F=\frac{\text { number of samples containing a species }}{\text { number of samples collected }}
$$

\section{Relative Frequency}

$$
F R=\frac{\text { frequency of a species }}{\text { sum of frequencies of all spp. }} \times 100
$$

\section{Results and discussions}

\subsection{Macroinvertebrate benthic}

There is different of macroinvertebrate benthic density in 2015 and 2017 (Figure 2). Macroinvertebrate benthic were mostly abundant in Code Streams. In 2015, total benthic founded in Winongo were $186 \mathrm{ind} / \mathrm{m}^{3}$, in Code were $716 \mathrm{ind} / \mathrm{m}^{3} \mathrm{ind} / \mathrm{m}^{3}$, and in Gajahwong were 336 $\mathrm{ind} / \mathrm{m}^{3}$. In 2017 , total benthic founded in Winongo were $30 \mathrm{ind} / \mathrm{m}^{3}$, in Code were $202 \mathrm{ind} / \mathrm{m}^{3}$, and in Gajahwong were $42 \mathrm{ind} / \mathrm{m}^{3}$. Both 2015 and 2017 were 
dominated by Chironomids larvae (Figure 3). In 2017 Oligochaeta worms were dominated in Code, they were found $143 \mathrm{ind} / \mathrm{m}^{3}$ causing declining of Chironomids larvae density, they were only $30 \mathrm{ind} / \mathrm{m}^{3}$ found. Only few predators were founded, and none EPT members were found. Code also have the highest species number, there were 9 species found and 7 species found in Code and Gajahwong. In total there were 20 species found in Winongo, Code, and Gajahwong. Species found in these three streams were quite similar.

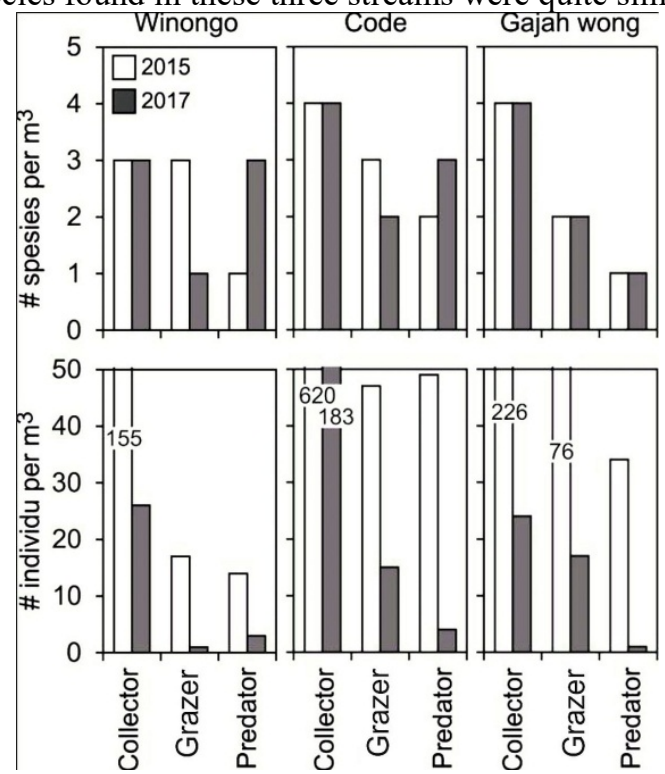

Fig. 2. Macroinvertebrate benthic densities in Winongo, Code, and Gajahwong. Light color: density 2015 and dark color: density 2017. Benthic in Code were the most dense.

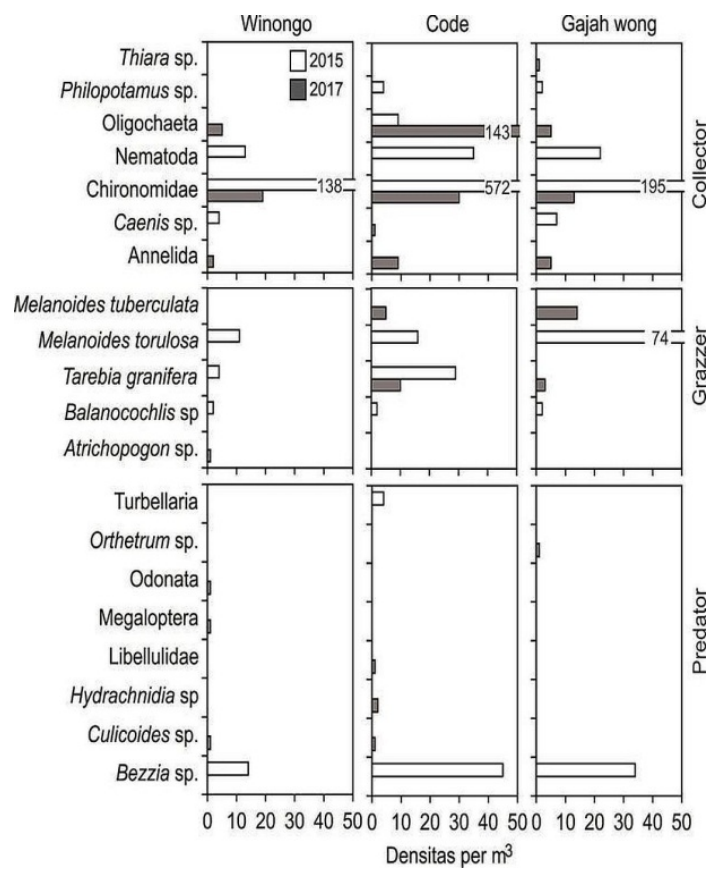

Fig. 3. Number of species found in Winongo, Code, and Gajahwong streams. There were only three FFG and total 20 species found. Chironomidae were dominated in all streams.

\subsection{Water quality}

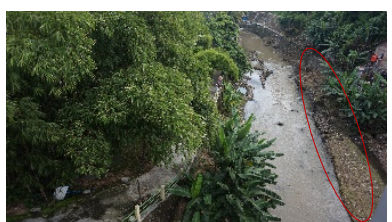

Code 2015

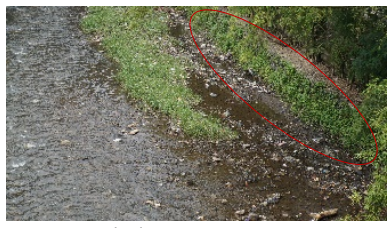

Gajahwong 2015

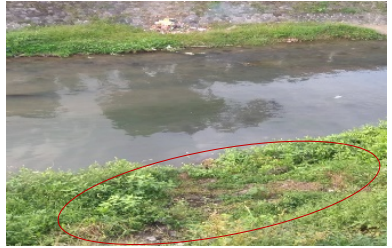

Winongo 2015

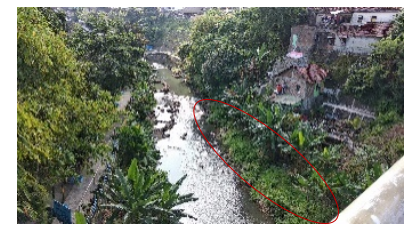

Code 2017

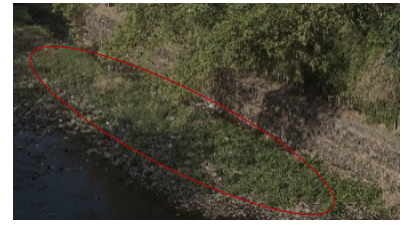

Gajahwong 2017

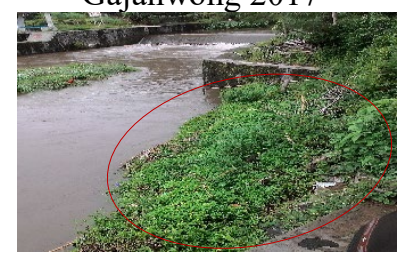

Winongo 2017
Fig. 4. Riparian vegetation on Winongo, Code, and Gajahwong stream in 2015 and 2017.

From the data shown in Figure 4., water quality were better in 2017 than 2015. Dissolved Oxygen in three streams were higher in 2017 than in 2015. Winongo had the highest DO compared to the other two streams. Dissolved oxygen in 2015 was $8.06 \mathrm{ppm}$ and $8.32 \mathrm{ppm}$ in 2017. Code DO was $6.69 \mathrm{ppm}$ in 2015 and $8.41 \mathrm{ppm}$ in 2017. While the lowest DO was in Gajahwong, it was $6.59 \mathrm{ppm}$ in 2017 and $8.30 \mathrm{ppm}$ in 2017. Winongo water $\mathrm{pH}$ closer to neutral than Code and Gajahwong. It was 8.11 in 2015 and 7.93 in 2017 . The highest ph is Code streams, it was 8.53 in 2015 and 8.24 in 2017. Water temperature were decreasing from 2015 to 2017 in these three streams. Code has the highest water temperature, it was $27{ }^{\circ} \mathrm{C}$ in 2015 and $25.72{ }^{\circ} \mathrm{C}$ in 2017. Gajahwong water temperature was $26.62{ }^{\circ} \mathrm{C}$ in 2015 and $25.78{ }^{\circ} \mathrm{C}$ in 2017 . Winongo has the lowest water temperature, it was $24.67^{\circ} \mathrm{C}$ in 2015 and 24.00 ${ }^{\circ} \mathrm{C}$ in 2017.

All streams in Yogyakarta City were suffered from urbanization. They receive huge amount of organic matterials and chemical waste. Macroinvertebrate benthic respond to these ecosystems changes. Their densities were declining sharply from 2015 to 2017. This was probably because urbanization altered channel moprhology. In return streams hydrology become flashy, flashy means more frequent, larger flow events with faster descending and ascending limbs of the hydrograph [21]. These events washed up sediments for benthic organisms caused sharp declining of biotic density and richness. Almost every part of streams bank in Yogyakarta City damming for fulfilling rapid growth of human population. Damming and fragmentation can be a major disturbance to streams ecosystems and macroinvertebrate community that are responsive to impoundment, they can be valuable indicators in assessing the health of streams ecosystems [22]. 


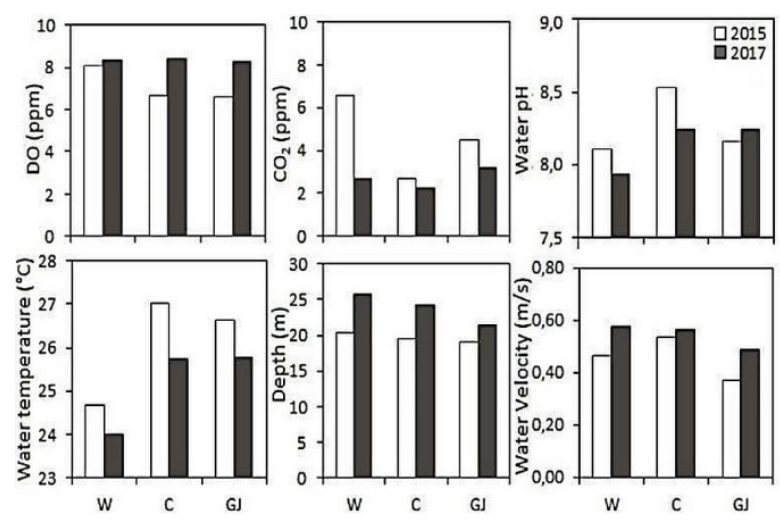

Fig. 5. Physic-chemical parameters in Winongo (W), Code (C), and Gajahwong (GJ). Trends showed water quality are better in 2017 than 2015. Winongo has better water quality compared to Code and Gajahwong streams

There were only three Functional Feeeding Group (FFG) of benthic found in Winongo, Code, and Gajahwong streams. Species number were low, only 20 was found. This was because riparian zone were damaged and in some area there were no riparian zone as it used for residential. Loss of riparian zone are limiting benthic community habitat. From fig. 5., water quality in these three streams were not quite different, for this reason they shared similar benthic species. Streams species richness were loss due to urbanization where all riparian zone are damaged by anthropogenic activities. No EPT was found in all three streams showed water quality were quite bad. Groups of EPT can only live in good quality water with high DO, good water transparency, low chemical pollutant, and low organic matter. The absent of EPT is an indicator that streams in Yogyakarta City were polluted.

The most abundant FFG is Collectors. Their densities are high in all three streams. Collectors most abundant in Code streams, there were $620 \mathrm{ind} / \mathrm{m}^{3}$, followed by Gajahwong $226 \mathrm{ind} / \mathrm{m}^{3}$ then Winongo 155 $\mathrm{ind} / \mathrm{m}^{3}$ in 2015 . But in 2017 , benthic density decline sharply leave only $183 \mathrm{ind} / \mathrm{m}^{3}$ in Code, $26 \mathrm{ind} / \mathrm{m}^{3}$ in Winongo, and $24 \mathrm{ind} / \mathrm{m}^{3}$ in Gajahwong. Code streams probably most suffered from urban growth. Northern part of Site 1 stand hospital and very crowded recidence, the area are getting more crowded to the southern part in site 3 . Domestic waste directly drains to streams through pipes, without contact to surrounding pervious land. In consecutives high input of organic material enter water ecosystem and cause disturbance for biotic richness. Collectors immediately respond to this sufficient input of organic materials, their density and diversity peak in Code and Gajahwong streams.

Streams in Yogyakarta City receive high input of domestic waste daily. Winongo main pollutant resources come from domestic, hospital, and aquaculture wastes. Code main pollutan resources are domestic waste, and agriculture, while Gajahwong main pollutan resources are domestic waste, Industrial waste from silver production, and zoo waste. Data showed that water quality better in 2017 than in 2015 . This was probably due to high rainfall along 2016 causing water debit increased thus water velocity washed faster organic matter downstream. Water physic-chemical parameters my not be used as main parameters to show water quality in this case as macroinvertebrate benthic community showed streams water quality decreasing. Urbanization takes stream bank to build more residential thus eliminate watersediment interaction and its ability to reduce toxicity.

\section{Conclusion}

Macroinvertebrate benthic are suitable as streams health indicator. Streams in Yogyakarta City were all enriched by high organic matter causing disturbance of benthic community. Their densities was decreasing from 2015 to 2017. Chironomids in all streams were abundant due to high organic matter. Water physicchemical factors can't be used as streams health indicators as they were strongly affected by rainfall.

Authors would like to thank Dinda Islami, and Fitria Ratna Pratiwi for their assistance during field sampling.

\section{References}

1. A.J. Horne, C.R. Goldman. Limnology, $2^{\text {nd }} E d$. McGraw-Hill, Inc. 356-383 (1994)

2. S.A. Al-shami., C. Salmah., A. Hassan., S. Abdul., S. Azizah., M. Nor. Ecotoxicology and environmental safety influence of agricultural, industrial, and anthropogenic stresses on the distribution and diversity of macroinvertebrates in Juru River Basin, Penang, Malaysia. Ecotoxicology and Environmental Safety, 74(5), 1195-1202. Available at http://dx.doi.org/10.1016/j.ecoenv.2011.02.022. (2011)

3. A. Ramirez., R. De Jesus-Crespo., D.M. MartinoCardona., N. Martinez-Rivera., S. BurgosCaraballo. Urban streams in Puerto Rico: what can we learn from the tropics?. The North American Benthological Society, 28(4): 10701079 (2009)

4. B.J.F.V. Rosa, L.F.T. Rodriguez, G.S. Oliveira, R.G. Alves. Chironomidae and Oligochaeta for water quality evaluation in an urban river in southeastern Brazil. Environ. Monit. Assess. 186, 7771-7779 (2014)

5. N. Bonada, N. Prat, V.H. Resh, B. Statzner. Developments in aquatic insect biomonitoring: A comparative analysis of recent approaches. Annual Review Entomology, 51, 495-523 (2006)

6. H.B.N Hynes. The biology of polluted waters. Liverpool University Press. 202 pp. (1960)

7. V.H. Resh. Multinational, freshwater biomonitoring programs in the developing world: Lessons learned from African and southeast Asian river surveys. Environmental Management, 39, 737-748 (2007)

8. J.G. Brito, T.M. Renato, C.O. Vivian, H. Neusa, L.N. Jorge, M.H. Robert, S.F.B. Ferraz, R.P. Felipe. Biological indicators of diversity in tropical streams: Congruence in the similarity of invertebrate assemblages. Ecology Indicator, 85, 85-92 (2018) 
9. I.C. Campbell, C.C. Bruce, H.R. Vincent. The development and application of biomonitoring in Lower Mekong River system. Chapter 13. Academic Press. 321-333 pp (2009)

10. K.W. Cummins, R.W. Merritt, P.C.N. Andrade. The use of invertebrate functional group to characterize ecosystem attributes in selected streams and rivers in south Brazil. Studies on Neotropical Fauna and Environmental, 40(1), 69-89 (2005)

11. R.T. Martins, S.R. Couceiro, A.S. Melo. M.P. Moreira, N. Hamada. Effects of urbanization on stream benthic invertebrate communities in Central Amazon. Ecol. Indic. 73, 480-491 (2017)

12. V.H. Resh. Which group is best? Attributes of different biological assemblages used in freshwater biomonitoring programs. Environmental Monitoring and Assessment. 1(3), 131-138 (2008)

13. A.E. Siegloch, R. Schmitt, M. Spies, M. Petrucio, M.I.M. Hernández. Effects of small changes in riparian forest complexity on aquatic insect bioindicators in Brazilian subtropical streams. Mar. Freshw. Res. 68, 519-527 (2017)

14. S. Habib, A.R. Yousuf. Benthic macroinvertebrate community of Yousmarg streams (Doodganga stream and Khanshah Manshah canal) in Kashmir Himalaya, India. Journal of Ecology and the Environment, 4(11), 280-289 (2012)

15. M.Z. Azrina, C.K.Ã. Yap, A.R. Ismail, A. Ismail, S.G. Tan. Anthropogenic impacts on the distribution and biodiversity of benthic macroinvertebrates and water quality of the Langat River, Peninsular Malaysia. Ecotoxicology and Environmental Safety. 64, 337-347 (2006)

16. Badan Lingkungan Hidup DIY. Dokumen informasi kinerja pengelolaan lingkungan hidup daerah. Available at http://blh.jogjaprov.go.id/pocontent/uploads/Buku_Data_IKPLHD_DIY_2016 . pdf (2016)

17. C.B. Angela, J. Carmona-Jiménez, T. GonzálezMartínez, M. Mazari-Hiriart. Hydrological evaluation of a peri-urban stream and its impact on ecosystem services potential. Global Ecology and Conservation. 3, 628-644 (2015)

18. C. He, S.B. Malcom, K.S. Dahlberg, B. Fu. A conceptual framework for integrating hydrological and biological indicators into watershed management. Landsc. Urban Plann, 49, 25-34 (2000)

19. F.W. Stehr. Immature Insects, Vol 1. Kendall/ Hunt Publishing, Dubuque, Iowa. 974 pp. (1987)

20. F.W. Stehr. Immature Insects, Vol 2. Kendall/ Hunt Publishing, Dubuque, Iowa. 974 pp. (1991)

21. C.J. Walsh, A.H. Roy, J.W. Feminella, P.D. Cottingham, M. Peter, R.P. Morgan II. The urban stream syndrome: current knowledge and the search for a cure. Journal of the North American Benthological Society, 24(3), 706-723 (2005)
22. K.A. Blocksom, B.R. Johnson. Development of a regional macroinvertebrate index for large river bioassessment. Ecological Indicators, 9, 313-328 (2009) 